www.cya.unam.mx/index.php/cya

\title{
Contracting debt and the quality of financial reporting in private firms
}

\author{
Contratando deuda y la calidad de la información financiera en \\ firmas privadas
}

\author{
Inna Sousa Paiva* \\ Instituto Universitário de Lisboa (ISCTE-IUL), Portugal
}

Received 4 September 2017; accepted 25 January 2018

Available online 29 May 2018

\begin{abstract}
This study investigates whether the quality of firms' financial reporting is influenced by the contracting of debt, using data on Portuguese private firms from 2013 to 2015. More specifically, the study uses earnings smoothing, magnitude of absolute discretionary accruals, and timeliness of disclosure as proxies for financial reporting quality. I find that private firms which contract more debt exhibit higher levels of financial reporting quality. Additionally, firms that contract larger amounts of debt and with a good financial performance tend to exhibit lower quality financial reporting. The results provide strong evidence that private firms have an interest in camouflaging their performance in the presence of higher levels of bank debt.
\end{abstract}

JEL classification: M41; G32; G20.

Keywords: Private firms; Financial reporting; Bank debt; Discretionary accruals ;Timeliness.

\footnotetext{
* Corresponding author.

E-mail address: inna_paiva@iscte.pt

Peer review under the responsibility of Universidad Nacional Autónoma de México.
} 


\section{Resumen}

Este estudio investiga si la calidad de la información financiera de las empresas se ve influenciada por el aumento de la deuda, utilizando los datos de las empresas privadas portuguesas de 2013 a 2015. Más concretamente, el estudio utiliza el alisamiento de los resultados, la magnitud de los ajustes discrecionales absolutos y la puntualidad de divulgación como medidas de calidad de informe financiero. Los resultados muestran que las empresas privadas que contratan más deudas presentan niveles más altos de calidad de informes financieros. Además, las empresas que contratan grandes cantidades de deuda y con un buen rendimiento financiero tienden a mostrar informes financieros de menor calidad. Los resultados proporcionan una fuerte evidencia de que las empresas privadas tienen interés en camuflar su desempeño en presencia de niveles más altos de deuda bancaria.

Códigos JEL: M41; G32

Palabras clave: Empresas privadas; Informe financiero; Deuda bancaria; Acreditaciones discrecionales; Puntualidad de divulgación.

\section{Introduction}

It is now widely recognized that access to finance fosters growth and competition and is therefore of the utmost importance for the economy, and for firms in particular. Private firms often find it difficult to raise debt or equity. The European Commission has gradually been working with financial institutions to improve the funding available to small and medium firms (SME) by stimulating the provision of loans and venture capital through financial instruments. European Union programs like Competitiveness of Enterprises and SMEs, Horizon 2020, European Structural and Investment Funds, and the Employment and Social Innovation program seek to boost lending and risk capital for SMEs (European Commission, 2015). Nevertheless, the private debt market remains a predominant source of new external funding for most private firms (Ding et al., 2016).

The quality of publicly reported financial information of firms is relevant to the world economy as external users make decisions based on this information and depend on its accuracy. A large number of research studies have shown that firms exercise discretion in the preparation of financial statements and use accounting policies to affect earnings levels, with the main purpose of influencing financial reporting numbers. The extensive previous literature has focused on publicly listed companies and discussed the better earnings quality of these firms (Leuz et al., 2003; Ball \& Shivakumar, 2005; Francis et al., 2005). While the quality of financial reporting and contracting debt has been studied in listed firms, limited research has been conducted on the financial reporting choices of private firms (Gassen \& Fülbier, 2015).

The objective of the present study is to fill this gap by investigating whether financial reporting quality is influenced by the bank relationship in private firms. To this end, the empirical analysis was conducted in Portuguese private firms for 2013-2015. The Portuguese private firm is an interesting setting to study the influence of the lending relationship on financial reporting quality. My choice of the Portuguese context to examine medium-sized private firms with similar agency problems and similar reporting and disclosure rules is explained by the following three reasons. First, private firms are of great relevance to the Portuguese economy. More specifically, they form a large proportion, about $96 \%$, of total businesses. Second, banking 
debt is a predominant source of new external funding for most private firms. Finally, Portugal is classified as the country of civil-law origin with the highest ownership concentration (La Porta et al., 1998).

I measure the lending relationship using the ratio of bank debt divided by total liabilities (Choi, 2007). I focus on three dimensions of financial reporting quality: (i) earnings smoothing, which is equal to the correlation between standard deviation in net income and the standard deviation in operation cash flow; (ii) absolute value of discretionary accruals estimated according to Dechow et al. (1995); and (iii) timeliness of disclosure proxied by the difference between the actual date of publication of the financial report and the mandatory date of disclosure.

I find strong and robust evidence that private firms contracting larger amounts of debt exhibit higher quality financial reporting. The results suggest that these firms conduct less earnings smoothing, report a lower level of absolute discretionary accruals, and the delay in disclosure of financial reporting is shorter. Controlling for other variables, the results show that as the contracting of debt increases, the quality of financial reporting improves significantly.

Findings also show that firms contracting larger amounts of debt and with a good financial performance tend to exhibit lower quality financial reporting. Private firms with these characteristics have an interest in camouflaging their performance, perhaps to avoid attracting competitors to the market or sector of activities.

This study makes several contributions to the literature. First, it contributes to the understanding of the relationship between contracting debt and financial reporting quality in the Portuguese context. Little is known about the lending relationship in European firms because most empirical evidence is based on the US (Bharath et al., 2011; 2008). Second, whereas most literature addresses the lending relationship in listed firms, my focus is on the relationship between lending and financial reporting quality in private firms. I investigate medium-sized private firms where banking debt is a predominant source of new external funding. Finally, this study has practical implications for regulators, namely, it raises concern about the need for regulatory enforcement to improve the financial reporting quality in private firms.

The remainder of the study is organized as follows. The next section reviews previous literature about the lending relationship and financial reporting quality and presents our hypothesis. In the third section, we describe the data, variables and research method. The fourth section presents the descriptive analysis and regression results. Section five presents the conclusions of this study.

\section{Related literature and hypothesis}

The lending relationship is defined as a long-term implicit contract between a bank and its debtor. Due to information production and repeated interaction with the borrower over time, the bank accumulates private information and establishes close ties with the borrower (Ongena et al., 2012). It is recognized in the literature that these ties allow the lending institution to provide certain benefits: reduction of asymmetric information, increased credit availability, and more efficient decisions if borrowers face financial distress (Boot \& Thakor, 2000; Gassen \& Fülbier, 2015).

In general, lenders will be concerned with the accuracy and reliability of the reported financial statements; in particular, it is important that a firm's earnings, assets, liabilities, and cash flows are reported accurately. However, it is difficult to measure and quantify shortcomings 
when a firm has material weaknesses, because credit issues are usually only found in the details of the quantitative and qualitative analysis (Colquitt, 2007).

Debt contracts involve management, creditors, and shareholders. It is assumed that there is a two-fold relationship between contracting debt and financial reporting quality.

First, according to agency theory in the capital structure literature, contracted debt may lead to problems due to the divergence between the interests of shareholders and debtholders (Jensen \& Meckling, 1976). Creditors are concerned about potential capital transfers from companies to shareholders, while managers are willing to favor the interests of shareholders to the disadvantage of creditors. The agency costs of debt can be mitigated by adjusting the properties of the debt contracts. The creditors would be able to modify and enforce debt contracts if they were granted the legal right to do so.

Additionally, large investors may also have more incentives to monitor managers (Jensen \& Meckling, 1976; Shleifer \& Vishny, 1986), reducing the agency costs of equity. The previous literature states that firms with higher contracted debt tend to disclose more information and have a higher level of accounting quality in order to reduce asymmetries and the agency costs of debt.

Moreover, proprietary costs theory developed by Verrecchia (1983) and Dye (1985) is based on the notion that managers take into account their concern about reputation and visibility and are likely to sense that the cost of supplying non-proprietary information to the public is minimal. This encourages managers to disclose more informative financial reporting in order to reduce the information asymmetry problem and, consequently, to decrease the cost of capital.

Second, debt can also have a negative influence on quality of earnings. Various agency conflicts between managers, owners and creditors can arise. Creditors secure their interests by designing contracts that limit a firm's ability to make decisions contrary to their interests. Broadly, debt contracts commonly contain covenants based on accounting numbers or ratios. Firms can modify the earnings reported when there are changes in accounting rules and principles, but debt covenants may include clauses that limit how the firm reports earnings (Smith, 1993). Studies show that firms manage earnings upward before the violation takes place. However, the findings depend on the level of financial distress in the sample of firms. Healthy firms that expect a permanent waiver do not manage earnings.

In this line, there is somewhat conflicting evidence from DeAngelo et al. (1994) and Sweeney (1994) on earnings management related to debt covenants. Both papers predicted that companies would engage in income-increasing behavior to avoid costly violation of debt covenants; there was no significant difference between the accrual behavior of companies with binding and nonbinding covenants. DeAngelo et al. (1994) provided some evidence that the more troubled companies with binding constraints had more negative accruals, but the accruals were related to inventory write-offs, which are probably a result of real problems and not discretionary decisions. In contrast, Sweeney (1994) found evidence that companies respond with more income-increasing accounting changes as they approach the violation of their debt covenants. Additionally, Dichev and Skinner (2002) uncovered unusual patterns in reported current ratios and net worth around the thresholds for these variables set in private debt agreements. Jaggi and Lee (2002) offered evidence that potentially reconciles the conflicting results. They found that some financially distressed companies use income-increasing discretionary accruals whereas others use income-decreasing discretionary accruals to manage earnings. By examining income smoothing, the study of Li and Richie (2016) provides evidence for whether income smoothing 
enhances the quality of information disclosure, which can be further translated into a lower cost of debt. Authors also report that the effect of earnings smoothing on debt cost reduction is stronger in firms with more opaque information and greater distress risk. These studies were conducted for listed companies and the results on contracting debt and the quality of financial reporting are not conclusive.

Private firms often find it difficult to raise debt or equity due to the lack of promising assets. Compared to publicly listed firms that have access to both equity and debt financing, privately held firms do not have privilege to access capital in the equity markets. Hence, private held firms rely primarily on debt financing to satisfy their operational needs (Ding et al., 2016). Most private businesses maintain a relationship with their commercial bank as it will facilitate their access and needed to financing (Berger \& Udell, 1998; Berger et al., 2011).

Empirical studies demonstrate that the lending relationship increases credit availability for private firms (Bharat et al., 2011). More informative financial reporting is meant to improve access to financing. Hence, private firms are interested in maintaining a relationship with creditors and disclosing informative financial reporting. In this line, Kim et al. (2011) using a list of privately owned Korean firms, found evidence that private audited firms have a significantly lower cost of debt. In a more recent study, Chen et al. (2015) show that firms voluntarily adopting International Accounting Standards (IAS) increased their access to foreign banks, because the adoption of IAS leads to improved accounting information quality. Ding et al. (2016) explore the relationship between financial reporting quality and private held debt financing in China and found that better earnings quality increases private firms' access to debt financing and lowers their cost of debt.

Previous studies show that firms contracting higher debt generally have higher quality of financial reporting. Gassen and Fülbier (2015) investigate the relation between creditor financing and earnings smoothing for European private firms and found that leverage firms and firms with lower ownership concentration report lower smoothing, reflecting a higher quality of accounting numbers. In the same line, Bigus and Hillebrad (2017) found that financial reporting quality in private firms decreases as the number of banking relationships goes down. Additionally, the authors found that firms with fewer bank relationships publish their financial report later and are more likely to do so after the mandatory deadline.

Banks are likely to examine the financial report of borrowers because banks will compare with other sources of financing, and they will also evaluate the exposure of firms to higher risk of default (Chen et al., 2011). Prior research suggests that better financial transparency mitigates information risk, and reduces the cost of debt. High quality financial reporting enables firms that contract debt to increase credit availability for private firms, and to assess the overall risk of the borrower when deciding whether to provide the loan. On the other hand, high quality accounting information helps creditors evaluate the borrower's ability to generate cash flow and to pay the loan.

In short, I test the following hypothesis:

Hypothesis: Private firms contracting a higher level of debt exhibit higher quality financial reporting. 


\section{Data, variables and methodology}

\section{Sample and data}

The empirical study investigates medium-sized private Portuguese firms between 2013 and 2015. Portugal is classified as the country of civil-law origin with the highest ownership concentration (La Porta et al., 1998). Additionally, the predominance of small and micro-sized companies in greater than the number of listed companies. This provides an interesting setting to investigate the influence of the lending relationship on financial reporting quality in private firms.

I focus on private firms because the agency problems that arise differ from those in public firms. Their controlling interests put them at a significant advantage over minority shareholders and could therefore provide greater opportunities for private rent extraction (Demsetz \& Lehn, 1985). Additionally, financial reporting rules are different for private and public firms .

I focus on the medium-sized private firms using the criteria of total assets, sales and number of employees. ${ }^{2}$ I do not include small private firms as the financial reporting requirements are much more simplified than for medium firms. Hence, the analysis concentrates on mediumsized private firms with similar agency problems and similar reporting and disclosure rules.

Data used to compute dependent and other independent variables are collected from the Amadeus Database and from each company's website. From the initial sample, I employ the following filters: first, I exclude finance industry firms because they operate in a highly regulated industry with different legal rules from those of other industries. Second, I delete firms with incomplete data to compute our dependent and independent variables. Third, I winsorized all variables at $1 \%$ and $99 \%$ percentile. The final sample is composed of a balanced panel of 540 firm-year observations in the three years (180 firms in each year).

\section{Measurement of dependent variables}

Following Bhattacharya et al. (2003), Leuz et al. (2003) and Bharath et al. (2008), and to capture different dimensions of the quality of financial reporting, I use earnings smoothing, earnings management and timeliness of disclosure.

Earnings smoothing. Leuz et al. (2003) state that managers of firms may use their discretion to report accounting numbers that offset economic shocks to a firm's operating cash flow, and this can affect the quality of financial reporting. That is, managers of firms may consider both a positive and negative cash flow shock to be unwelcome as it reveals the firm's actual performance.

Thus, I capture earnings smoothing as the correlation between the standard deviation in income before taxes and the standard deviation in operating cash flow (Burgstahler et al., 2006; Dou et al., 2013; Leuz et al., 2003):

$$
\mathrm{SMOOTH}_{i, t}=\sigma\left(\text { Net Income }_{i, t}\right) / \sigma\left(\mathrm{CFO}_{i, t}\right)
$$

\footnotetext{
${ }^{2}$ In accordance with Decree Law nr 158/2009, of 13 July, a medium-sized entity is understood to be one that has not exceeded two of the following three limits in the last three years: total assets of 20,000,000 euros, total sales of $40,000,000$ euros and an annual average of 250 employees. Note that the criteria defining the limits for a medium entity in Portugal were altered on 1 January 2016; however, as the empirical analysis covers the period from 2013 to 2015 , the criteria in force up to 2015 were applied.
} 
Where, $\sigma\left(\right.$ Net Income $\left._{i, t}\right)$ is the standard deviation of net income before taxes for firms i year $\mathrm{t}$, divided by total of assets at the end of the year $\mathrm{t} ; \sigma\left(\mathrm{CFO}_{\mathrm{i}, \mathrm{t}}\right)$ is the standard deviation of cash from operations for firm i year divided by total of assets at the end of the year $\mathrm{t}$. In this model, the higher values correspond to little income smoothing and, consequently, better accounting quality.

Earnings management. Accruals are likely to capture evidence of earnings management because they reflect managers' accounting estimates and choices. Following Dechow et al. (1995), the magnitude of cross-sectional absolute discretionary accruals is calculated based on estimated abnormal accruals, where the latter are defined as total accruals minus estimated normal accruals.

I calculate total accruals (TA $i, t)$ as follows ${ }^{3}$ :

$$
T A_{i, t}=\Delta C A_{i, t}-\Delta C L_{i, t}-\Delta \operatorname{Cash}_{i, t}+\Delta S T D E B T_{i, t}-D E P N_{i, t}
$$

Where, $\Delta \mathrm{CA}_{i, t}$ is the change in current assets for firm $\mathrm{i}$ between year $\mathrm{t}-1$ and year $\mathrm{t} ; \Delta \mathrm{CL}_{i, t}$ is the change in current liabilities for firm i between year t-1 and year t; $\Delta$ Cash $_{i, t}$ is the change in cash for firm $\mathrm{i}$ between year $\mathrm{t}-1$ and year $\mathrm{t}$; $\triangle \mathrm{STDEBT}_{i, t}$ is the change in debt in current liabilities for firm $\mathrm{i}$ between year $\mathrm{t}-1$ and year $\mathrm{t}$; $\mathrm{DEPN}_{i, t}$ is the depreciation and amortization expense for firm $\mathrm{i}$, in year $\mathrm{t}$. All numbers are scaled by average total assets for firm $\mathrm{i}$, year $\mathrm{t}-1$ $\left(\mathrm{A}_{\mathrm{i}, \mathrm{t}-1}\right)$.

Following Dechow et al. (1995), discretionary accruals are represented by the error term of the following equation, based on a cross-sectional estimation with at least 10 observations by industry and year cluster:

$$
\frac{T A_{i, t}}{A_{i, t-1}}=\alpha_{1} \frac{1}{A_{i, t-1}}+\alpha_{2} \frac{\left(\Delta R E V_{i, t}-\Delta A R_{i, t}\right)}{A_{i, t-1}}+\alpha_{3} \frac{P P E_{i, t}}{A_{i, t-1}}+\varepsilon_{i, t}
$$

Where $\triangle \mathrm{REV}_{i, t}$ is the change in sales for firm i between year t-1 and year t; $\triangle \mathrm{AR}{ }_{i, t}$ is the change in account receivables for firm i between year $\mathrm{t}-1$ and year $\mathrm{t}$; PPE $\mathrm{i}_{\mathrm{i}, \mathrm{t}}$ is the gross amount of properties, plants and equipment for firm i year $\mathrm{t}$; $\mathrm{A}_{\mathrm{i}, \mathrm{t}-\mathrm{l}}$ is average total assets for firm $\mathrm{i}$, year $t$ and $t-1$. A higher magnitude of the cross-sectional absolute value of discretionary accruals (DA) indicates a greater level of earnings management, or lower accounting quality and viceversa.

Timelines of disclosure. The timing of disclosure of financial reporting is another dimension of financial reporting quality. Timeliness refers to the need for accounting information to be presented in a timely manner to users so that it meets their decision making needs. Delaying the disclosure of the information reduces the value of that information (Hutton et al., 2009). We measure timelines by DELAY, which is calculated as the number of days between the

\footnotetext{
${ }^{3}$ Daske, Gebhardt, and McLeay (2006) and Dechow (1994) also use accounting provisions and tax payables to calculate total accruals. Since the Amadeus database generally lacks data on these variables, I have omitted these variables to calculate TA.
} 
mandatory date for publishing the financial reporting and the actual date of its publication. The smaller the number of days' delay, the higher the level of financial reporting quality.

\section{Measurement of independent variables}

Contracting of debt. Previous literature uses several proxies to capture the lending relationship, namely: the number of banking relationships, duration of the relationship with a bank, the size of the largest financing portion (Ongena et al., 2012; Bigus \& Hillebrand, 2017; Choi, 2007; Bharath et al., 2008). The Amadeus database has some limitations. For example, it does not include data on the banking relationships of Portuguese firms. Thus, in line with Choi (2007), I define the lending relationship by calculating the debt contraction variable (DEBT), which is the ratio of bank debt divided by total liabilities. In order to further validate results, I also use an alternative measure, high debt contraction (HIGH_DB) as the dummy variable that takes the value 1 for firms superior or equal to median contracting of debt and 0 otherwise. High levels of the debt contracting ratio (DEBT) indicate a lending relationship.

Control variables. The control variables that may also affect management manipulation are firm size (SIZE), frequency of reported negative earnings (LOSS), cash flow from operations (CFO), profitability (ROA), investment opportunity (GROWTH) and firm's risk (RISK). As a proxy for firm size (SIZE), I use the natural logarithm of annual total assets. I expect larger firms to have higher quality financial reporting; these firms have strong management and are concerned about reputation and visibility. Closer scrutiny by stakeholders can potentially reduce the managers' opportunities to exercise their accounting discretion in larger firms.

Negative earnings may induce managers to use more accruals to mitigate the impact of losses, and motivate them to use accounting discretion. As a control for negative earnings (LOSS), I use the dummy variable that takes the value 1 if the firm presented a net loss for the fiscal period and 0 otherwise. More incidences of loss may induce managers to use more accruals to mitigate the impact of the losses, which would negatively affect the quality of accruals (Francis et al., 2004). I expect the quality of financial reporting to be lower in firms with more frequent losses.

Greater cash flow (CFO) indicates liquidity and more uncertainty in the operating environment. I measure this variable as the cash flow from operations scaled by beginning of year total assets. In a setting of greater uncertainty, managers need to use their judgment more often, so there is a higher probability of error estimation and poorer quality financial reporting (Francis et al., 2004).

When firms have a strong economic performance, they face less pressing demands from stakeholders and this signals the presence of economic rents. These rents could proxy a rich investment opportunity that calls for additional external financing; it thus provides an incentive for better quality accounting numbers. A strong performance reduces the need and incentive to manipulate earnings (Cascino et al., 2010). I measure economic performance as the return on assets (ROA) and expect firms with a better financial performance to have a higher quality financial reporting.

I control for a firm's growth opportunities by using annual sales growth (GROWTH). Although growth firms present more important investment opportunities, financing future investment implies a higher cost of capital. Therefore, growth firms have relatively strong incentives for accounting discretion, and this may help avoid increases in the cost of capital 
(Sánches-Ballesta \& García-Meca, 2007). I expect firms with growth opportunities to have lower quality financial reporting.

I also considered the relationship between risk firms (RISK) and financial reporting quality, because riskier firms will have greater incentives to manipulate earnings in order to reduce the perception of risk (Warfield et al., 1995) or to reduce the cost of equity capital. I control for RISK as the standard deviation of gross profit divided by lagged total assets. I expect that firms with higher risk to have lower quality of financial reporting.

\section{Model}

I explore the contracting of debt and financial reporting quality by estimating:

$$
\operatorname{QUALITY}_{i, t}=\beta_{0}+\beta_{1} \text { DEBT }_{i, t}+\beta_{2} \operatorname{SIZE}_{i, t}+\beta_{3} \operatorname{LOSS}_{i, t}+\beta_{4} \mathrm{CFO}_{i, t}+\beta_{5} \text { ROA }_{i, t}+\beta_{6} \text { GROWTH }_{i, t}+\beta_{7} R_{I S K_{i, t}}+\operatorname{SIC}_{n}+\gamma_{t}+\varepsilon_{i, t}
$$

Where QUALITY stands for the financial reporting quality measures, defined in Table 1, for SMOOTH, DA, DELAY separately. I explore the principal model represented in equation (4) by estimation submodel (1), where QUALITY = SMOOTH, by estimation submodel (2), where QUALITY = DA, and by estimation submodel (3), where QUALITY = DELAY.

The main independent variable is DEBT, which represents the ratio of bank debt divided by total liabilities. SIZE is the natural logarithm of annual total assets. LOSS is the dummy variable that takes the value 1 if the firm presented a net loss for the fiscal period and 0 otherwise. CFO is the cash flow from operations scaled by total assets at the beginning of year. ROA is the return on assets. GROWTH is the annual sales growth. RISK is the standard deviation of gross profit divided by lagged total assets. $\mathrm{SIC}_{\mathrm{n}}$ captures industry-fixed effects, $\gamma_{t}$ is the year dummies and $\varepsilon_{i, t}$ is the error term. Table 1 shows the definition and measurement of all dependent and independent variables. 
Table 1

Definition of variables

\begin{tabular}{|c|c|c|}
\hline Variable & Variable name & Variable Measurement \\
\hline Earnings smoothing & SMOOTH & $\begin{array}{l}\text { The correlation between the change in the operating income and the } \\
\text { change in operating cash flow. }\end{array}$ \\
\hline Earnings management & DA & $\begin{array}{l}\text { The firm-level of the three-year absolute value of discretionary } \\
\text { accruals estimates according to Dechow et al (1995). }\end{array}$ \\
\hline Timeliness of disclosure & DELAY & $\begin{array}{l}\text { The firm-level difference in days between the actual date on which } \\
\text { the financial report was disclosed and the mandatory disclosure date. }\end{array}$ \\
\hline Debt contracting & DEBT & The ratio of bank debt divided by total liabilities. \\
\hline High debt contracting & HIGH_DB & $\begin{array}{l}\text { The dummy variable with the value } 1 \text { for firms superior or equal to } \\
\text { median contracting of debt and } 0 \text { otherwise. }\end{array}$ \\
\hline Firm size & SIZE & The natural logarithm of a firm's total assets at the end of year. \\
\hline Negative earnings & LOSS & $\begin{array}{l}\text { The dummy variable that takes the value } 1 \text { if the firm represented a net } \\
\text { loss for the fiscal period and } 0 \text { otherwise. }\end{array}$ \\
\hline Liquidity & $\mathrm{CFO}$ & The cash flow from operations scaled by beginning of year total assets. \\
\hline Profitability & ROA & $\begin{array}{l}\text { Net income before taxes and interest expenses in the fiscal year } \\
\text { divided by total assets at the start of fiscal year. }\end{array}$ \\
\hline Sales growth & GROWTH & Change in a firm's total sales at the end of year over the three years. \\
\hline Risk & RISK & The standard deviation of gross profit divided by lagged total assets. \\
\hline
\end{tabular}

\section{Results}

\section{Descriptive statistics and correlations}

Table 2 summarizes the descriptive statistics. Panel A illustrates the results obtained for financial reporting quality variables. 
Table 2

Descriptive statistics

\begin{tabular}{lcrrrr}
\hline \multicolumn{1}{c}{ Variable } & \multicolumn{1}{c}{$\begin{array}{c}\text { Standard } \\
\text { Deviation }\end{array}$} & $\begin{array}{c}10^{\text {th }} \\
\text { percentile }\end{array}$ & Median & \\
\hline Panel A: Dependent variables & & & & \\
\hline SMOOTH & 0.50 & 0.34 & 0.18 & 0.47 & 0.67 \\
DA & 0.05 & 0.04 & 0.01 & 0.04 & 0.07 \\
DELAY & 18 & 58 & -50 & 20 & 60 \\
\hline Panel B: Main independent variables & & & & 0.80 \\
\hline DEBT & 0.57 & 0.29 & 0.10 & 1 & 1 \\
HIGH_DB & 0.48 & 0.52 & 0 & & 10.20 \\
\hline Panel C: Control variables & & & & 6.68 & 1.00 \\
\hline SIZE & 8.56 & 2.06 & 5.76 & 0.00 & 0.34 \\
LOSS & 0.30 & 0.40 & 0.00 & 0.03 & 0.18 \\
CFO & 0.05 & 0.20 & 0.00 & 0.06 & 5.85 \\
ROA & 0.05 & 0.06 & 0.11 & 1.64 & 0.33 \\
GROWTH & 2.87 & 4.25 & 0.70 & 0.18 & \\
RISK & 0.23 & 0.06 & 0.06 & & \\
\hline
\end{tabular}

For a definition of variables, see Table 1.

The mean of earnings smoothing (SMOOTH) is 0.50 and the mean value of discretionary accruals (DA) is 0.05 . All values are slightly higher than in private European firms (Cascino et al. (2010) reported 0.47 and 0.042 respectively for Italian firms; Gassen \& Fülbier, 2015 reported 0.54 for European firms). The mean delay in firm disclosure of financial reporting is 18 days. This is a higher value than the mean reported in German firms (Bigus \& Hillebrand, 2017). Panel $B$ demonstrates the results for the debt contracting variables. The mean value of the proportion of bank debt (DEBT) is 0.57 , which indicates that private medium firms are quite involved in banking relationships. The alternative variable of contracting high debt (HIGH_DB) presented a mean value of 0.48 . Descriptive statistics for control variables are provided in Panel C. The mean values are: 8.56 for SIZE, 0.30 for LOSS, 0.05 for CFO, 0.05 for ROA, 0.05 for ROA, 2.87 for GROWTH and 0.22 for RISK. These values are consistent with previous studies (Bigus \& Hillebrand, 2017; Cascino et al., 2010; Sánches-Ballesta \& García-Meca, 2007).

Finally, Table 12 presents the pair-wise Pearson correlation among all continuous variables. Our first dependent variable, earnings smoothing (SMOOTH), is negatively correlated with the DEBT, SIZE, ROA and RISK variables. The second dependent variable, discretionary accruals (DA), is negatively associated with DEBT, SIZE and RISK variables. Finally, our third dependent variable, timeliness (DELAY) is negatively associated with DEBT, SIZE, CFO, ROA, GROWTH and RISK. This is consistent with prior research on earnings quality 
providing evidence that higher leverage firms and profitable firms are more likely to reduce managers' opportunities to exercise their accounting discretion in these firms.

Table 3

Pearson correlation matrix for continuous variables

\begin{tabular}{lllllllllll}
\hline & SMOOTH & DA & DELAY & DEBT & SIZE & CFO & ROA & GROWTH & RISK & VIF \\
\hline SMOOTH & 1 & & & & & & & & & 2.07 \\
DA & 0.367 & 1 & & & & & & & & 2.40 \\
DELAY & 0.655 & 0.090 & 1 & & & & & & & 1.03 \\
DEBT & $-0.365^{* * * *}$ & $-0.564^{* * *}$ & $-0.345^{* *}$ & 1 & & & & & & 4.76 \\
SIZE & $-0.654^{* * *}$ & $-0.653^{* * *}$ & $-0.236^{* *}$ & 0.534 & 1 & & & & & 3.89 \\
CFO & 0.156 & 0.118 & -0.127 & -0.025 & 0.045 & 1 & & & & 2.69 \\
ROA & -0.191 & $0.222^{*}$ & $-0.054^{* * *}$ & $-0.665^{* *}$ & $0.137^{*}$ & $0.367 *$ & 1 & & & 7.02 \\
GROWTH & $0.432^{*}$ & $0.211^{* *}$ & -0.365 & 0.024 & 0.462 & 0.010 & $0.453^{*}$ & 1 & & 3.48 \\
RISK & -0.037 & -0.235 & 0.246 & 0.024 & -0.536 & 0.137 & -0.127 & -0.06 & 1 & 1.00 \\
\hline
\end{tabular}

As Table 3 show, there are no pairwise correlation coefficients in excess of 0.80 , indicating that the threat of multicollinearity is limited. The highest coefficient represents the value -0.665 between ROA and DEBT. However, we also conduct a formal test to ensure that multicollinearity is not present in our sample. In particular, we calculate the Variance Inflation Factor (VIF) for each independent continuous variable included in the estimated model. Kennedy (1992) suggests that a VIF greater than ten is indicative of problematic multicollinearity. As Table 12 shows, the highest VIF value is 7.02, which is well below 10 (i.e. the value indicating that multicollinearity might be present) (Kennedy, 1992). Therefore, we conclude that multicollinearity is not a problem in our sample.

\section{Multivariate results}

Tables 4 provides the results of estimations of the regression model for the total sample in this analysis. The parameters of equation (4) are estimated using the most appropriate methodology, pooled or panel data (fixed or random effects) regression, based on the results from the Breusch-Pagan and the Hausman tests. The Breusch-Pagan Lagrange Multiplier and the Hausman tests were conducted for each submodel separately in order to determine which type of regression - pooled, fixed effects or random effects - is more appropriate to describe the relationship between the earnings quality and the explanatory variables included in the equations (4). The Hausman test indicates no rejection of a null hypothesis (the significance is 0.06 for submodel 1, 0.87 for submodel 2 and 1.05 for submodel 3) and the Breusch-Pagan test shows rejection of a null hypothesis (the significance is 0.00 for three submodels), what indicates that the random effects is more appropriate for all submodels estimated for columns $\mathrm{C} 1, \mathrm{C} 2$ and $\mathrm{C} 3$.

The results of three submodels are presented: column $\mathrm{C} 1$ includes QUALITY $=$ smoothing, column C2 includes QUALITY = discretionary accruals and column C3 includes QUALITY $=$ timeliness. The results show that as the contracting of debt increases, the quality of financial reporting improves significantly. Reported regression results in column $\mathrm{C} 1$ demonstrate that the coefficient on DEBT is -0.103 at the $1 \%$ level, suggesting that firms contracting higher debt conduct less earnings smoothing. Results in column $\mathrm{C} 2$ demonstrate that the coefficient 
on DEBT is -0.050 at the $1 \%$ level, suggesting that firms contracting higher debt report a lower level of absolute discretionary accruals. Reported regression results in column $\mathrm{C} 3$ demonstrate that the coefficient on DEBT is -20.10 at the $5 \%$ level, suggesting that firms contracting higher debt have a shorter delay, in days, of the disclosure of financial reporting. These findings are consistent with the arguments presented in support of the hypothesis as well as with previous studies that private firms with strong bank relationships exhibit higher levels of financial reporting quality (Bigus \& Hillebrand, 2017; Gassen \& Fülbier, 2015; Bharath et al., 2008).

Table 4

Estimated regressions of financial reporting quality

\begin{tabular}{|c|c|c|c|c|}
\hline \multirow[t]{2}{*}{ Variables } & \multirow[t]{2}{*}{ Predicted sign } & (C1) SMOOTH & (C2) DA & (C3) DELAY \\
\hline & & $\begin{array}{l}\text { Coef. } \\
\text { (p value) }\end{array}$ & $\begin{array}{l}\text { Coef. } \\
\text { (p-value) }\end{array}$ & $\begin{array}{l}\text { Coef. } \\
\text { (p-value) }\end{array}$ \\
\hline Intercept & & $\begin{array}{l}0.017 * * * \\
(5.60)\end{array}$ & $\begin{array}{l}0.038^{* * * *} \\
(6.05)\end{array}$ & $\begin{array}{l}48.45^{* *} \\
(4.26)\end{array}$ \\
\hline DEBT & - & $\begin{array}{l}-0.103 * * * \\
(3.07)\end{array}$ & $\begin{array}{l}-0.050 * * * \\
(3.83)\end{array}$ & $\begin{array}{l}-20.10 * * \\
(2.46)\end{array}$ \\
\hline SIZE & - & $\begin{array}{l}-0.028 * * \\
(2.22)\end{array}$ & $\begin{array}{l}-0.017 * * * \\
(2.93)\end{array}$ & $\begin{array}{l}-0.001 * * \\
(2.08)\end{array}$ \\
\hline LOSS & + & $\begin{array}{l}1.89 * * * \\
(3.24)\end{array}$ & $\begin{array}{l}0.020 \\
(0.146)\end{array}$ & $\begin{array}{l}-1.892 \\
(0.24)\end{array}$ \\
\hline $\mathrm{CFO}$ & + & $\begin{array}{l}0.172 \\
(0.190)\end{array}$ & $\begin{array}{l}0.350 \\
(1.07)\end{array}$ & $\begin{array}{l}32.45 \\
(0.95)\end{array}$ \\
\hline ROA & - & $\begin{array}{l}0.17 \\
(0.10)\end{array}$ & $\begin{array}{l}0.012 \\
(0.143)\end{array}$ & $\begin{array}{l}-98.45^{* * * *} \\
(3.26)\end{array}$ \\
\hline GROWTH & + & $\begin{array}{l}0.002 * * \\
(2.25)\end{array}$ & $\begin{array}{l}0.003 * \\
(1.89)\end{array}$ & $\begin{array}{l}-0.008 \\
(0.041)\end{array}$ \\
\hline RISK & - & $\begin{array}{l}-0.25 \\
(0.95)\end{array}$ & $\begin{array}{l}-0.67 \\
(0.52)\end{array}$ & $\begin{array}{l}120.89 \\
(0.56)\end{array}$ \\
\hline Industry effects & & Included & Included & Included \\
\hline Year effects & & Included & Included & Included \\
\hline $\mathrm{N}$ & & 540 & 540 & 380 \\
\hline Adj. $R^{2}$ & & 0.12 & 0.11 & 0.08 \\
\hline $\begin{array}{l}\text { F-stat. } \\
\text { (P-value) }\end{array}$ & & $\begin{array}{l}4.578 \\
(0.000)\end{array}$ & $\begin{array}{l}10.670 \\
(0.000)\end{array}$ & $\begin{array}{l}2.987 \\
(0.000)\end{array}$ \\
\hline
\end{tabular}

For a definition of variables, see Table 1.

$*, * *$ and $* * *$ indicates significance at the $1 \%, 5 \%$ and $10 \%$ levels, respectively.

The results for the control variables are also interesting. Firm size (SIZE) is found to be significantly negative, which implies that larger firms disclose their information more often and therefore have less tendency to manipulate earnings. The coefficients are not significant for 
either cash flow (CFO) or risk (RISK), suggesting that these two variables do not affect a firm's decision to smooth earnings, manipulate their accruals or delay the disclosure of financial reporting. The coefficient of profitability (ROA) is significant and negative for timeliness of disclosure, signifying that firms with higher profitability are less likely to delay the disclosure of financial information. The coefficient of the reporting of losses (LOSS) is significant and positive for earnings smoothing, suggesting that firms with higher losses tend to conduct more earnings smoothing. Finally, the significant and positive coefficient of firms growth (GROWTH) on smoothing and discretionary accruals suggests that firms with higher sales growth tend to smooth and manipulate earnings.

After taking the interaction variables into account, some important findings emerge. According to previous literature, loss firms reported aggressiveness of earnings and less informative financial reporting (Bharath et al., 2011). Firms with a higher performance level report their earnings in a timely manner. Hence, I investigate whether the association between contracting debt and financial reporting quality depends on the characteristics of the borrowing firms. I take into account the risk variable (RISK), performance (ROA) and growth (GROWTH) and interact with DEBT in order to measure the marginal lending relationship and financial reporting quality. We estimated the regression model of financial reporting quality using interaction variables. The results are presented in Table 5.

Table 5

Estimated regressions of financial reporting quality using characteristics of firms

\begin{tabular}{|c|c|c|c|c|}
\hline \multirow[t]{2}{*}{ Variables } & \multirow{2}{*}{$\begin{array}{l}\text { Predicted } \\
\text { sign }\end{array}$} & (C1) SMOOTH & (C2) DA & (C3) DELAY \\
\hline & & $\begin{array}{l}\text { Coef. } \\
\text { (p value) }\end{array}$ & $\begin{array}{l}\text { Coef. } \\
\text { (p-value) }\end{array}$ & $\begin{array}{l}\text { Coef. } \\
\text { (p-value) }\end{array}$ \\
\hline Intercept & & $\begin{array}{l}0.000 * * * \\
(7.60)\end{array}$ & $\begin{array}{l}0.001 * * * \\
(10.05)\end{array}$ & $\begin{array}{l}88.45^{* * * *} \\
(8.26)\end{array}$ \\
\hline ROA & - & $\begin{array}{l}0.12 \\
(0.15)\end{array}$ & $\begin{array}{l}0.20 \\
(0.02)\end{array}$ & $\begin{array}{l}87 * * * \\
(2.96)\end{array}$ \\
\hline ROA_DEBT & - & $\begin{array}{l}0.028 * * * \\
(3.278)\end{array}$ & $\begin{array}{l}0.017 \\
(0.08)\end{array}$ & $\begin{array}{l}12^{*} \\
(1.95)\end{array}$ \\
\hline GROWTH & + & $\begin{array}{l}1.89 * * * \\
(3.24)\end{array}$ & $\begin{array}{l}0.020 \\
(0.146)\end{array}$ & $\begin{array}{l}-1.892 \\
(0.24)\end{array}$ \\
\hline GROWTH_DEBT & + & $\begin{array}{l}0.172 \\
(0.78)\end{array}$ & $\begin{array}{l}0.350 \text { *** } \\
(3.07)\end{array}$ & $\begin{array}{l}32.45 \\
(0.95)\end{array}$ \\
\hline RISK & - & $\begin{array}{l}-0.17 \\
(0.10)\end{array}$ & $\begin{array}{l}-0.012 \\
(0.143)\end{array}$ & $\begin{array}{l}-98.45 \\
(0.876)\end{array}$ \\
\hline RISK_DEBT & - & $\begin{array}{l}0.004 \\
(0.476)\end{array}$ & $\begin{array}{l}0.003 \\
(0.890)\end{array}$ & $\begin{array}{l}-0.008 \\
(0.041)\end{array}$ \\
\hline Industry effects & & Included & Included & Included \\
\hline Year effects & & Included & Included & Included \\
\hline $\mathrm{N}$ & & 540 & 540 & 380 \\
\hline Adj. $R^{2}$ & & 0.08 & 0.09 & 0.04 \\
\hline F-stat. (P-value) & & $\begin{array}{l}3.853 \\
(0.000)\end{array}$ & $\begin{array}{l}8.029 \\
(0.000)\end{array}$ & $\begin{array}{l}2.536 \\
(0.0002)\end{array}$ \\
\hline
\end{tabular}

For a definition of variables, see Table 1.

$*, * *$ and $* * *$ indicates significance at the $1 \%, 5 \%$ and $10 \%$ levels, respectively. 
The coefficient of the interaction variable (ROA_DEBT) is significant and positive for timeliness of disclosure and earnings smoothing. These findings also show that firms contracting larger amounts of debt and with a good financial performance tend to exhibit lower quality financial reporting. Therefore, private firms with these characteristics have an interest in camouflaging their performance, perhaps to avoid attracting competitors to the market. The coefficient of the interaction variable (GROWTH_DEBT) is significant and positive for earnings management. These findings suggest that firms with a larger level of debt and higher growth tend to exhibit a lower quality of financial reporting.

\section{Sensitivity analyses}

I conduct several sensitivity tests to assess the robustness of the results reported. First, I confirm whether the results with panels corrected standard errors which allow for heteroscedasticity in the panel structure of my data. Secondly, I check whether the results of the models are robust to an alternative measure of contracting debt. I calculate the contracting high debt (High_DB) variable and estimate the research model of financial reporting quality. Untabulated analyses show that contracting high debt is significantly and negatively related to different measures of financial reporting quality, confirming my previous findings.

\section{Conclusion}

This study investigates whether the quality of firms' financial reporting is influenced by the contracting of debt, using data on Portuguese private firms from 2013 to 2015. I find strong and robust evidence that private firms contracting larger amounts of debt exhibit higher levels of financial reporting quality. The results suggest that these firms conduct less earnings smoothing, report a lower level of absolute discretionary accruals, and the delay in disclosure of financial reporting is shorter. Controlling for other variables, the results show that as the contracting of debt increases, the quality of financial reporting improves significantly.

I also investigate whether the association between contracting debt and financial reporting quality depends on the characteristics of the borrowing firms. Findings show that firms contracting larger amounts of debt and with a good financial performance tend to exhibit lower quality financial reporting. Private firms with these characteristics have an interest in camouflaging their performance, perhaps to avoid attracting competitors to the market. Additionally, findings also show that firms contracting larger amounts of debt and higher growth tend to exhibit higher level of earnings management, consequently, lower quality financial reporting.

There are several promising avenues for further research. The results of this study evidence that private firms contracting larger amount of debts exhibit higher quality of financial reporting. However, there are other external characteristics, for example, the state of the economy, that can influence quality of financial reporting of these firms. Empirical literature on this has argued that during recession periods, companies may experience more difficulties in contracting debt and that some of them become more leveraged (Lin et al., 2014). Do the recession and expansion periods influence the quality of financial reporting in private firms? Further research might examine whether the relationships found in this study can be extended to other firms and periods.

Further research is clearly needed to capture incentives of earnings management through debt, governance, and country effects in private firms. For instance, it would be interesting 
to further explore this relationship using a structural equation model, trying to combine the relationship of the dependent variables for the latent variable with the quality of financial reporting (Afiah \& Rahmatika, 2014). Hence, building financial reporting quality models that capture the firm-level and country- level characteristics of private firms is both a challenge and an opportunity.

\section{References}

Afiah, N.N. \& Rahmatika, D. N. (2014). Factors influencing the quality of financial reporting and its implications on good government governance. International Journal of Business, Economics and Law, 5(1), 111-121.

Ball, R., \& Shivakumar, L. (2005). Earnings quality in UK private firms: Comparative loss recognition timeliness. Journal of Accounting and Economics, 39(1), 83-128. http://dx.doi:10.1016/j.jacceco.2004.04.001.

Berger, A. F., \& Udell, G. F. (1998). The economics of small business finance: The roles of private equity and debt markets in the financial growth cycle. Journal of Banking and Finance, 22 (6-8), 613-673. http://dx.doi:10.1016/ S0378-4266(98)00038-7.

Berger, A. N., Klapper, L. F., \& Udell, G. F. (2001). The ability of banks to lend to informationally opaque small businesses. Journal of Banking and Finance, 25 (12), 2127-2167. http://dx.doi:10.1016/S0378-4266(01)00189-3.

Berger, A. N., Miller, N., Petersen, M., Rajan, R., \& Stein, J. (2005). Does function follow organizational form? Evidence from the lending practices of large and small banks. Journal of Financial Economics, 76 (2), 237-269. http:// dx.doi:10.3386/w8752.

Berger, A. N., Rosen, R. J., \& Udell, G. F. (2007). Does market size structure affect competition? The case of small business lending. Journal of Banking and Finance, 31 (1), 11-33. http://dx.doi:10.1016/j.jbankfin.2005.10.010.

Bharath, S. T., Dahiya, S., Saunders, A., \& Srinivasan, A. (2011). Lending relationships and loan contract terms. Review of Financial Studies, 24 (4), 1141-1203. http://dx.doi:10.1093/rfs/hhp064.

Bharath, S.T., Sunder, J., \& Sunder.S.V. (2008). Accounting quality and debt contracting. Journal of Accounting Review, 83 (1), 1-28, http://dx.doi:10.2308/accr.2008.83.1.

Bhattacharya, U., Hazem, D., \& Welker, M. (2003). The world pricing of earnings opacity, The Accounting Review, 78(3), 641-678.

Bhattacharya, S., \& Chiesa, G. (1995). Proprietary information, financial intermediation, and research incentives. Journal of Financial Intermediation, 4, 328-357. http://dx.doi:10.1006/jfin.1995.1014.

Bigus, J. \& Hillebrand. (2017). Bank relationships and provate firms' financial reporting quality. European Accounting Review, 26 (2), 379-409. http://dx.doi:10.1080/09638180.2016.1152906.

Bigus, J., Georgiou, N., \& Schorn, P. (2016). Legal form and earnings properties. European Accounting Review, 25 (3), 515-548. http://dx.doi:10.1080/09638180.2015.1051566.

Boot, A. W. A. (2000). Relationship banking: What do we know? Journal of Financial Intermediation, 9 (1), 7-25. http://dx.doi:10.1006/jfin.2000.0282.

Boot, A., \& Thakor, A. (2000). Can relationship banking survive competition? Journal of Finance 55 (2), 679-713. http://dx.doi:10.1111/0022-1082.00223.

Burgstahler, D. C., Hail, L., \& Leuz, C. (2006). The importance of reporting incentives: Earnings management in European private and public firms. The Accounting Review, 81 (5), 983-1016. http://dx.doi:10.2308/accr.2006.81.5.983.

Cano-Rodríguez, M. (2010). Big auditors, private firms and accounting conservatism: Spanish evidence. European Accounting Review, 19 (1), 131-159. http://dx.doi:10.1080/09638180902989426.

Cascino, S., Pugliese, A., Mussolino, D., \& Sansone, C. (2010). The influence of family ownership on the quality of accounting information. Family Business Review 23 (3), 246-265. http://dx.doi:10.1177/0894486510374302.

Chen, F., O.-K. Hope, Q., Li, \& Wang, X. (2011). Financial Reporting Quality and Investment Efficiency of Private Firms in Emerging Markets, The Accounting Review, 86(4), 1255-88. https://doi.org/10.2139/ssrn.1635425.

Chen, Q., Ding, S., Wu, Z., \& Yang, F. (2015). Family Control, International Accounting Standards, and Access to Foreign Banks: Evidence from International Entrepreneurial Firms, Journal of Small Business Management, 54(2), 598-621. https://doi.org/10.1111/jsbm.12160. 
Choi, W. (2007). Bank relationships and the value relevance of the income statement: Evidence from income-statement conservatism. Journal of Business Finance and Accounting, 34 (7-8), 1051-1072. http://dx.doi:10.1111/j.1468-5 957.2007.02023.x.

Colquitt, J. (2007). Credit Risk Management: How to Avoid Lending Disasters and Maximize Earnings. (3 $3^{\text {rd }}$ Ed.). McGarw-Hill. http://dx.doi:10.1036/0071446605.

Daske, H., Gebhardt, G., \& McLeay, S. (2006). The distribution of earnings relative to targets in the European Union. Accounting and Business Research, 36 (3), 137-167. http://dx.doi:10.1080/00014788.2006.9730019.

DeAngelo, H., DeAngelo, E., \& Skinner, D. (1994). Accounting Choice in Troubled Companies. Journal of Accounting and Economics, 17 (1-2), 113-143. http://dx.doi.org/10.1016/0165-4101(94)90007-8.

Dechow, P. M. (1994). Accounting earnings and cash flows as measures of firm performance: The role of accounting accruals. Journal of Accounting and Economics, 18 (1), 3-42. http://dx.doi:10.1016/0165-4101(94)90016-7.

Dechow, P. M., \& Dichev, I. D. (2002). The quality of accruals and earnings: The role of accrual estimation errors. The Accounting Review, 77 (Supplement), 35-59. http://dx.doi:10.2307/3203324.

Dechow, P. M., Sloan, R. G., \& Sweeney, A. P. (1995). Detecting earnings management. The Accounting Review, 70 (2), 193-225. http://dx.doi:10.2307/248303.

Demsetz, H. \& Lehn, K. (1985). The structure of corporate ownership: Causes and consequences. Journal of Political Economy, 93 (6), 1155-1177. http://dx.doi.org/10.1086/261354.

Dichev, I.D. \& Skinner, D.J. (2002). Large-Sample Evidence on the Debt Covenant Hypothesis, Journal of Accounting Research, 40(4), 1091-1123. https://doi.org/10.1111/1475-679X.00083.

Ding, S, Liu, M. \& Wu, Z. (2016). Financial Reporting Quality and External Debt Financing Constrains: The Case of Privately Held Firms, Abacus, 3(52), 351-373. https://doi.org/10.1111/abac.12083.

Dou, Y., Hope, O.-K., \& Thomas, W. T. (2013). Relationship-specificity, contract enforceability, and income smoothing. The Accounting Review, 88, 1629-1656. doi:10.2308/accr-50489.

Dye, R.A. (1985). Disclosure of non-proprietary information. Journal of Accounting Research, 23 (1), 123-145. http:// dx.doi:10.2307/2490910.

European Comission. (2015). Investing in jobs and growth- maximising the contribution of European Structural and Investment Funds, COM (2015) 639 final, Brussels, available https://ec.europa.eu/research/openvision/pdf/rise/ jakimowicz-osimo-mayer-mureddu-vigo_financial_instruments.pdf.

Francis, J., LaFond, R., Olsson, P., \& Schipper, K. (2004). Cost of equity and earnings attributes. The Accounting Review, 79 (4), 967-1010. https://doi.org/10.2308/accr.2004.79.4.967.

Francis, J., LaFond, R., Olsson, P., \& Schipper, K. (2005). The market pricing of accruals quality. Journal of Accounting and Economics, 39 (2), 295-327. http://dx.doi:10.1016/j.jacceco.2004.06.003.

Gassen, J., \& Fülbier, R.U. (2015) Do creditors prefer smooth earnings? Evidence from European private firms. Journal of International Accounting Research, 14(2), 151-180. doi: 10.2308/jiar-51130.

Ghosh, A. \& Moon, D. (2010). Corporate Debt Financing and Earnings Quality. Journal of Business Finance and Accounting, 37(5-6), 538-559. https://doi.org/10.1111/j.1468-5957.2010.02194.x.

Hope, O.-K., Wayne, T. B., \& Vyas, D. (2013). Financial reporting quality of U.S. private and public firms. The Accounting Review, 88 (5), 1715-1742. http://dx.doi:10.2308/accr-50494.

Hutton, A. P., Marcus, A. J., \& Tehranian, H. (2009). Opaque financial reports, R2, and crash risk. Journal of Financial Economics, 94 (1), 67-86. http://dx.doi:10.1016/j.jfineco.2008.10.003.

Jaggi, B. \& Lee, P. (2002). Earnings management response to debt covenant violations and debt restructuring. Journal of Accounting, Auditing and Finance, 17 (4), 295-324. https://doi.org/10.1177/0148558X0201700402.

Jensen, M. \& Meckling, W. (1976). Theory of firm: Managerial behaviour, agency costs and ownership structure. Journal of Financial Economics, 3 (4), 305-360. https://doi.org/10.1016/0304-405X(76)90026-X.

Kennedy, P. (1992), A guide to econometrics ( ${ }^{\text {rd }}$ edition), Oxford, UK: Basil Blackwell Ltd.

Kim, J.,D. Simunic, M. Stein, \& Yi, C. (2011). Voluntary Audits and the Cost of Debt Capital for Privately Held Firms: Korean Evidence, Contemporary Accounting Research, 28(2), 585 615. https://doi.org/10.1111/j.19113846.2010.01054.x.

La Porta, R., Lopes-de-Silanes, F., Shleifer, A., \& Vishny, R. (1998). Law and Finance, Journal of Political Economy, 106 (6), 1113-1155. https://doi.org/10.1086/250042. 
Leuz, C., Nanda, D., \& Wysocki, P. (2003). Earnings management and investor protection: an international comparison. Journal of Financial Economics, 69 (3), 505-527. http://dx.doi:10.1016/S0304-405X(03)00121-1.

Li, S. \& Richie, N. (2016). Income smoothing and the cost of debt. China Journal of Accounting Research, 3(9), 175190. http://dx.doi.org/10.1016/j.cjar.2016.03.001

Lin, Z., Jiang, Y., Tang, Q, \& He, X. (2014). Does High-Quality Financial Reporting Mitigate the Negative Impact of Global Financial Crises on Firm Performance? Evidence from the United Kingdom, Australasian Accounting, Business and Finance Journal, 8(5), 19-46. doi:10.14453/aabfj.v8i5.3.

Lisboa, I. (2016). Impact of financial crisis and family control on earnings management of Portuguese listed firms, European Journal of Family Business, 6, 118-131. https://doi.org/10.1016/j.ejfb.2017.06.002.

Ongena, S., Tümer-Alkan, G., \& Westernhagen, N. (2012). Creditor concentration: An empirical investigation. European Economic Review, 56 (4), 830-847. http://dx.doi:10.1016/j.euroecorev.2012.02.001.

Peek, E., Cuijpers, R., \& Buijink, W. (2010). Creditors' and shareholders' reporting demands in public versus private firms: Evidence from Europe. Contemporary Accounting Research, 27 (1), 49-91. http://dx.doi:10.1111/j.1911-3 846.2010.01001.x.

Sánchez-Ballesta, J. \& García-Meca, E. (2007). Ownership structure, discretionary accruals and the informativeness of earnings. Corporate Governance: An International Review, 15 (4), 677-691. http://dx.doi:10.1111/j.1467-8683 .2007.00596.x.

Shleifer, A. \& Vishny, R. (1986). Large shareholders and corporate control. Journal of Political Economy, 94 (3), 461-488. http://dx.doi.org/10.1086/261385.

Smith, C. W. (1993). A perspective on accounting-based debt covenant violations. The Accounting Review, 68 (2), 289-303.

Sweeney, A. (1994). Debt-covenant violations and managers' accounting responses. Journal of Accounting and Economics, 17 (3), 281-308. https://doi.org/10.1016/0165-4101(94)90030-2.

Verrecchia, R. (1983). Discretionary disclosure. Journal of Accounting and Economics, 5 (1), 179-194. https://doi. org/10.1016/0165-4101(83)90011-3.

Warfield, T., J. Wild, J., \& Wild, K. (1995). Managerial ownership, accounting choices, and informativeness of earnings. Journal of Accounting and Economics, 20 (1), 61-91. https://doi.org/10.1016/0165-4101(94)00393-J. 